\title{
MICHAEL SHEPHERD
}

$$
\text { (1923-1995) }
$$

Michael Shepherd, the founding editor of this journal, died suddenly in late August, bringing an end to an era in British psychiatry. He was a man of massive erudition and a sharp, sardonic wit. $\mathrm{He}$ established epidemiological psychiatry and trained numerous workers in this country and abroad. His own contributions to epidemiological psychiatry were substantial, and his activity as an editor of books relating to the history of psychiatry, and in making works of European psychiatrists familiar to monoglot English readers were of great value.

Michael's grandparents came from Russia, and his father was born in the Swansea Valley, where he worked in the glass business. His father was a straightforward, simple man who was not ambitious for his eldest son; but always pleased and proud of Michael's achievements. He was among the top two or three boys of his year at Cardiff High School, equally at home in the arts and the sciences, and with a gift for languages that was to stand him in good stead in later life.

He studied medicine at Oxford, where he soon established himself in a new academic environment. His dissecting partner remembers him as intensely humorous, always sceptical about received truths and with a sardonic approach to authority. In his vacations he toured Europe with a rucksack and soon became fluent in French, Italian and German. He was keenly interested in pictures and music, and was able to amuse a roomful of friends by impersonating mutual acquaintances. Another life-long trait was also apparent at this stage: he would quiz his friends about their lives and show a genuine interest, yet he was guarded about his own affairs. Two other very important events occurred at Oxford: he met his future wife Margaret and he came under the influence of John Ryle.

His marriage was a close and happy one, and he was a devoted father and family man. He spent much time working at home and had very wide interests: art in all its forms, literature of all kinds, sport and classical music. Biographies formed one of the few bridges between his private and professional lives; the best case histories were to be found in literature. His wife protected him from daily domestic stresses, and her death, in 1992, after a protracted illness was a savage blow. He leaves behind two sons, two daughters and two grandchildren.

From John Ryle - first professor of social medicine at Oxford - he learned of the importance of social factors in human disease. Having demonstrated a case of cardiac asthma, Ryle described his own experience of anginal pain, and then asked the young Michael Shepherd how he thought the patient was going to cope with her disability at home. Michael having admitted his ignorance, Ryle suggested that he visit the patient at home. "Shortly afterwards I found myself on a Saturday afternoon cycling along a sidestreet in Cowley to learn something of the socio-medical significance of cardiac invalidism. Though obviously puzzled by the purpose of my visit that patient was clearly glad to see me. As I took my leave she asked me to convey her thanks to "the other doctor... I shall never forget his kind words", Ryle was undoubtedly a key influence on Michael: without him it is doubtful whether he would have become our first professor of epidemiological psychiatry.

It is of interest that he was an avid reader of psycho-analytical texts before he went to Oxford, but his time at medical school modified his interests. He went on, in the early 1950 s, to train in psychiatry under Aubrey Lewis. Lewis, who had filled the Maudsley with a rich assortment of diverse psychiatrists, was a major influence on Michael Shepherd. Michael set himself the task of studying the pattern of psychotic illness in the County of Buckinghamshire during two periods, 1931-3 and 1945-7. He was later to show that the major movement of the hospital population in 
terms of a higher discharge rate and shorter hospital stay had taken place 10 years before the introduction of psychotropic drugs, and could be largely attributed to the setting up of an unusually progressive mental health service in the area.

A later epidemiological study in Buckinghamshire took a large random sample of children between the ages of 5 and 15, and showed that a phenomenon like bedwetting was a feature of normal childhood. A case-control study of children attending a child guidance clinic showed that they differed from similar children not attending the clinics mainly in their parents' attitudes and ability to manage their child's behaviour. Two years later, there were no differences in outcome between the children seen by the clinic and the controls in the community.

At this time, he demonstrated his ability to write first class clinical papers by writing an account of morbid jealousy in which he described the complex interplay of clinical and social factors in the development of this common symptom. He went on to become the Reader in Psychiatry, a post that he occupied at the time when I first met him in 1964. He carried out clinical work for most of his professional life, and showed himself to be a shrewd clinician who encouraged his trainees to take careful histories, and to base their conclusions on observed facts rather than inference.

He had a mildly abrasive manner with those who knew him only slightly, and tended to tease his subordinates in various ways. Presenting cases to him was something of an ordeal, since he followed Aubrey Lewis's example by taking the notes from his junior doctor, and expecting a detailed presentation of the case from memory. He was unfailingly erudite, but also deeply interested in his patients' lives. As an interviewer he showed a rare ability to make intuitive leaps - a quality that was not encouraged in us. As a teacher he used the elenchic method, teaching by posing questions: most of them pretty difficult. On closer acquaintance one was struck by his unfailing helpfulness. This quality was not confined to a few chosen acolytes, but was the experience of all who went to him for help.

His major epidemiological work was Psychiatric Illness in General Practice, a work of great prescience, which has still not been surpassed. He took a large sample of London general practitioners and showed that their aggregated patients were representative of the population of Greater London. A one in ten sample of their patients was selected and all items of medical care over the course of a year were recorded. In this general morbidity study Shepherd and his colleagues clearly showed the relationship between physical and psychiatric morbidity, as well as showing how the vast majority of mentally ill people are treated by their family doctors rather than the mental health services. He followed this up by forming the General Practice Research Unit, of which he was the director until his own retirement, and which formed a nursery for a whole generation of young social psychiatrists to build on his original achievement. In addition to the solid programme of research that came out of the unit, Michael was very good company on our research days. He had a great sense of the absurd, and had a wonderful ear for the nuances in someone's speech, and an even better ability for inventing the words that he put into other people's mouths.

Following Aubrey Lewis's retirement he was appointed, after various vicissitudes, to the post of first professor of epidemiological psychiatry. In many ways this was the ideal job for him: he could establish the subject that was dearest to his heart, he was able to pursue various scholarly objectives and he was a thorn in the side of others in authority. Two other threads were equally important: these were his interest in psychopharmacology and the work he carried out for the World Health Organization. This work was to lead in three directions: in work on a triaxial classification; in studies of the detailed processes of interviewing using videotaped interviews; and in training workshops.

His activities as an editor were both important and extensive. He collaborated in the magnificent three volume Anatomy of Madness, produced Themes and Variations in European Psychiatry and edited The Later Papers of Sir Aubrey Lewis. As founding editor of this journal, Michael produced what may well be the most scholarly journal covering psychiatry and its allied sciences in the world. He inaugurated a system in which assessors separated remarks that were confidential to the editor from those that they were prepared to share with the author. Despite the system, comments sent back to me had always been fastidiously cut out with scissors: yet I was never able to determine 
whether I was being spared hurtful barbs, or whether critical comments that had been meant only for the editor were being shared with me.

Despite his formidable reputation at the Maudsley, as an examiner of undergraduates he was the personification of kindness: very rarely failing anyone, and going out of his way to learn things about the lives of the students he was examining. He was always very good company: never better than when I met him at a conference in Washington, at the Institute of Medicine, and revealed that I had a Visitor's Pass to the exclusive Cosmos Club. 'Let's go right away', said Michael, and we left earnest academics behind us, and for the next four hours I was regaled with all the gossip and anecdotes that I had missed in the year I had spent away from England.

His last lecture at the Institute of Psychiatry was the Mapother lecture, entitled 'The Two Faces of Emil Kraepelin', an abbreviated version of which has recently been published. ${ }^{1}$ It was the best lecture I have ever heard him give. His diction and timing were faultless - what Kenneth Rawnsley had described as an arrestingly mordant style of delivery: but so too was the content of what he had to say. It was copiously researched and scrupulous in paying tribute to Kraepelin's achievements. However, the criticism that followed was devastating, and delivered with a passion that Michael rarely allowed himself.

At dinner afterwards Michael told me that Frederick Mott had made the journey to Munich in 1909 to see Kraepelin and seek his advice. Kraepelin had written in his diary: 'An Englishman came to see me about opening a new mental hospital in London. It will come to nothing'. Well, the Maudsley has survived - and so has Psychological Medicine. The part played by Michael Shepherd in the creation of each has been critically important.

DAVID GOLDBERG Institute of Psychiatry, London.

\footnotetext{
1 Two faces of Emil Kraepelin. British Journal of Psychiarry 1995, 167, 174-183.
} 